\title{
The Effect Of Progressive Muscle Relaxation Interventions on Depression, Stress, Anxiety, and Quality Of Life For Cancer Patients: A Systematic Review
}

\author{
Sholihin $^{\mathrm{a}}$, Tria Anisa Firmanti ${ }^{\mathrm{a}}$, Muhammad Nashir ${ }^{\mathrm{a}}$, Roudlotun Nurul Laili ${ }^{\mathrm{a}}$ \\ ${ }^{a}$ Stikes Banyuwangi, Banyuwangi, East Java, Indonesia \\ Email Korespondensi: sholihin-2018@fkp.unair.ac.id
}

\begin{abstract}
Introduction: Patients with cancer experience emotional distress which characterized by psychological symptoms such as anxiety or depression, psychological symptoms that arise and complex cancer processes have negative impact on their quality of life. Many cancer patients use a wide variety of techniques to improve their psychological symptoms and quality of life including relaxation therapy and specifically, Progressive Muscle Relaxation (PMR). Method: The systematic review purpose was to review the evidence regarding the use of PMR intervention for cancer patients. Thirty four published studies and nine identified original article as potentially relevant, undertaken in the past six years until now (2013 to 2019) with data bases in Scopus, Proquest, Google Scholar, Oxford, and Science direct Searches. The information flow chart from record identification to study inclusion was conducted in accordance with the PRISMA and extracted data with PICOT. Results: The impact of progressive muscle relaxation interventions remained in effect for between seven days and six month after the interventions. Progressive muscle relaxation intervention is the technique including continous and systematic stretching and relaxing of the muscles until the whole body becomes relaxed. Conclusion: It has effects in improving depression, stress, anxiety and quality of life via physical relaxation.
\end{abstract}

Keywords: depression; stress; anxiety; quality of life; progressive muscle relaxation; cancer patients

\begin{abstract}
Abstrak
Pendahuluan: Penderita kanker mengalami tekanan emosional yang ditandai dengan gejala psikologis seperti kecemasan atau depresi, gejala psikologis yang muncul dan proses kanker yang kompleks berdampak negatif pada kualitas hidup mereka. Banyak pasien kanker menggunakan berbagai macam teknik untuk meningkatkan gejala psikologis dan kualitas hidup mereka termasuk terapi relaksasi dan khususnya, Relaksasi Otot Progresif (PMR). Metode: Tinjauan sistematis bertujuan untuk meninjau bukti penggunaan intervensi PMR pada pasien kanker. Tiga puluh empat penelitian yang diterbitkan dan sembilan artikel asli yang diidentifikasi berpotensi relevan, dilakukan dalam enam tahun terakhir hingga sekarang (2013 hingga 2019) dengan basis data di Scopus, Proquest, Google Scholar, Oxford, dan Science Direct Searches. Bagan arus informasi dari identifikasi rekaman hingga inklusi studi dilakukan sesuai dengan PRISMA dan mengekstrak data dengan PICOT. Hasil: Dampak intervensi relaksasi otot progresif tetap berlaku antara tujuh hari sampai enam bulan setelah intervensi. Intervensi relaksasi otot progresif adalah teknik yang meliputi peregangan dan relaksasi otot secara terus menerus dan sistematis hingga seluruh tubuh menjadi rileks. Kesimpulan: Ini memiliki efek dalam meningkatkan depresi, stres, kecemasan dan kualitas hidup melalui relaksasi fisik.
\end{abstract}


Kata kunci: depresi; menekankan; kecemasan; kualitas hidup; relaksasi otot progresif; pasien kanker

\section{INTRODUCTION}

Cancer is one of the health problems which grow rapidly in the world (Newoton S, Hicky $\mathrm{M}$, n.d.). And it is the number two cause of death in the world. Cancer and its treatment are the main factors that cause anxiety and depression (A. J. Mitchell, M. Chan, 2011; Bigliardi et al., 2017; C.-H. Chien, K.-L. Liu, H.-T. Chien, 2014). Patients with cancer experience emotional distress which characterized by psychological symptoms such as anxiety or depression, psychological symptoms that arise and complex cancer processes have negative impact on their quality of life (ParaÂs-BravoP \& Alonso-BlancoC, Paz-ZuluetaM, SantibañezMarguÈelloM, Palacios-CeñaD, 2017). Negative impact on the function and patients' quality are not only caused by the cancer process but also the complications, side effects of treatment, and the duration of cancer that is suffered (Lazovich D, Robien K, Cutler G, Virnig B, 2009).

Some studies showed that cancer and its treatment can cause physical, emotional and social problems that lead to decreased function, impaired sexual function, and body image changes, followed by structural changes and reduced self-confidence. Family problems, emotional, economic problems, the anxiety are the impact of psychological problems due to the decrease of psychological and physical functions which can affect individuals' quality of life and their families (Donavan KA, Thompson LM, 2013). Anxiety affects all biological, psychological, and social aspects and how human needs are met (de Souza JM, Ferrari GSL, 2017; Gethin, Grocott, Probst, \& Clarke, 2014; Kashdan TB, 2010; Shahbazi K, Solati K, 2016). Depression and anxiety can cause behavioral changes and affect treatment by attacking awareness, weakness, motivation, and reducing coping abilities and quality of life (Medicine, 2008)

Depression and anxiety are cancer symptoms that can stand for several years, which can cause negative effects on patients' quality of life, appropriate medical care, recurrence, survival and recovery from surgery during hospital care [13-16]. The negative impact of cancer diagnosis and the sequelae of cancer treatment, $20 \%-30 \%$ of breast cancer patients suffered depression and anxiety, which are significantly higher than the prevalence of appropriate depression and anxiety $(6 \%-8 \%)$ in healthy women $(\mathrm{Bj}$ orneklett , HG, Lindemalm, C., Rosenblad, A., Ojutkangas, ML, Letocha \& Strang, P., 2012). In China, the prevalence of anxiety, depression, or anxiety and depression in breast cancer patients were $21.1 \%, 34.4 \%$ and $15.6 \%$ (So, W.K., Marsh, G., Ling, W.M., Leung, F.Y., Lo, J.C., Yeung, M., et al., 2010). Based on WHO predictions, the incidence of cancer in Iran will reach 85,000 cases from all populations with a mortality rate of 62,000 in 2020 ("Noncommunicable Disease Profile," 2007). Based on an increase of the elderly population in the world (with an increase from 605 million in 2000 to 2 billion in 2050), the number of cancer patients is estimated to increase (Larrañaga N, Galceran J, Ardanaz E, Franch P \& Sánchez MJ, 2010). In the US, there were almost $60 \%$ elderly of 11 million cancer patients. In Iran, cancer is the third cause of death, and WHO reports $12 \%$ of deaths annually ("World Health organization. Noncommunicable Disease, Countries Profile," 2011).

Hormones such as adrenaline, glucagon, epinephrine, norepinephrine, and cortisol are correlated with stress. Particularly, cortisol is an important indicator of changing physiological conditions in stress response. Sensitivity to cortisol is greater than other hormones and seen in physical, mental and cognitive stress. There are several objective indicators of physiological responses, including blood pressure, heart rate, body temperature, and breathing (Han, H. J., Park, A., Kim, H. S., Moon, H. K., \& Park, 2011). According to P. J. Oh and Choi (2012), many cancer patients met stress, anxiety, depression, insomnia, and post-traumatic stress disorder. This stress can affect the nervous systems, endocrine, immune and interfere recovery through delayed wound healing, metabolic 
PROFESIONAL HEALTH JOURNAL

Volume 3, No. 1, Desember 2021 (Hal. 34-42)

Available Online at https:// http://jurnal.stikesbanyuwangi.ac.id

reactions, and changes in body composition after surgery or treatment (Broadbent, E., Kahokehr, A., Booth, R. J., Thomas, J., Windsor, J. A. \& M., 2012; Choi, J. H., \& Kim, 2013).

Several studies have confirmed that, proper care and intervention in cancer patients, such as complementary therapy can help relieve physical and psychological discomfort (Gaston-Johansson F, Fall-Dickson JM, Nanda JP \& Browall M, 2013). Relaxation has a significant psychological impact, by relaxation we can improve specific aspects of our personality, strengthen positive quality of life and change unwanted habits and attitudes (Kumar S, Nayak RR, 2015). Relaxation techniques have been used as effective supplementary therapies for anxiety and depression, adding the patient's ability in coping and self-care skills to reduce anxiety symptoms (A.F.Jorm, H.Christensen, K.M.Griffiths, R.A.Parslow \& Rodgers, 2004; S. Elsenbruch, J. Langhorst, 2005). Edmund Jacobson has found Progressive Muscle Relaxation Techniques (PMRT) in the 1920s as an intervention to help patients deal with anxiety and ensure that muscle relaxation can calm the mind (Kisner C, 2007). Progressive Muscle Relaxation (PMR) is a systematic technique used to achieve full relaxation and has been shown to improve quality of life related to health in medical and psychiatric diseases (T. Dehdari, A. Heidarnia, A. Ramezankhani, S. Sadeghian \& F. Ghofranipour, 2009). Progressive Muscle Relaxation Therapy (PMRT) is easy to learn, has no side effects, and can be done in all locations. The purpose of our systematic review was to review the evidence regarding the use of PMR intervention for cancer patients to improve depression, stress, anxiety,and quality of life via physical relaxation.

\section{METHOD}

\section{Research Literature}

There were four researchers who participated in searching the research literature. The English literature and publications over the past six years (2013 to 2019) with data bases in Scopus, Proquest, Google Scholar, Oxford, and Science direct journals were used. Keywords used in searching the literature were "Progressive Muscle Relaxation", AND "Cancer" AND "Anxiety", AND "Depression", AND "Stress", AND "Quality of Life". The literatures found with these keywords were thirty-four literatures.

\section{Article Selection}

The selected articles criteria in this systematic review were first, they might be original articles and they were not in the form of systematic reviews. Second, the articles discussed about Progressive Muscle Relaxation interventions and their combinations. Third, participants were people who were suffering from cancer which were not specific to certain cancers or treatments. The Fourth was interventions about progressive muscle relaxation in cancer patients. All authors on systematic review selected the appropriate article.

3. Data Extracted

Data taken in the found literature were themes, authors, population, intervention, combination, time needed to give intervention, results, follow-up, and the methods used (PICOT)

\section{RESULT}

There were thirty-four literatures obtained, four literatures were systematic review, three literatures had the same titles, eighteen literatures gave Progressive Muscle Relaxation (PMR) interventions not in cancer patients. One article discussed the effect of PMR on nurse students, an article discussed the effect of PMR on retirees, and one more article discussed the effect of PMR on patient's parents, and another article discussed about instruments to evaluate the effect of PMR.

There were ten articles selected for systematic review. Seven literatures used Randomize Control Trial (RCT) method, One literatures used quasi-experimental method, two literatures used pre-post design.

The total research population in all literatures was 60-222 people, after randomly selected; the final number of research respondents who were willing and qualified in all the literature was from 46 to 170 people. The intervention given in the literature is Progressive Muscle Relaxation (PMR) and 
several interventions combined with other interventions which are also complementary or non-medical alternative therapies. Three literatures provided PMR interventions without combination of other interventions, Three literatures combined PMR and Guide Image (GI), two literatures combined PMR and music, one literature combined PMR and one literature used three combinations of PMR, GI, and deep breath.

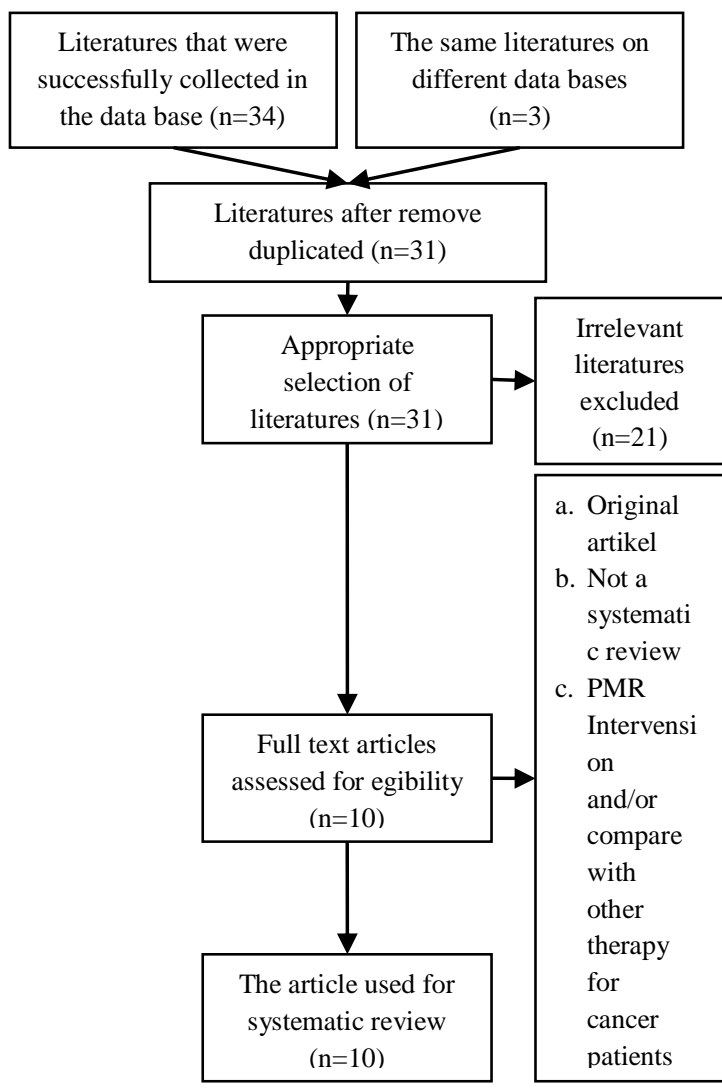

Figure. 1.Information flow chart

The first study combination of PMR and GI sessions for cancer patients. The intervention session was carried out in the respondent's house to minimize stress which is related to factors from the hospital medical environment (Charalambous, Giannakopoulou, Bozas, \& Paikousis, 2015). After being randomly selected, the control group received standard care (meeting weekly with a central psychologist) and the intervention group received 4 PMR and GI sessions which were monitored every day and unattended session for three weeks. Daily reminders (text messages) were given to the intervention group to remind them in practicing PMR and GI every day at the same time.

The Second study PMRT program was conducted by the experimental group before and after surgery for 5 days (Kim, Na, \& Hong, 2016). The researcher instructed participants to take twice a day program (7: 00-8: 00am and 7: 00-8: 00pm) for 5 days. The experimental group practiced PMRT with the researchers, who provided MP3 players and earphones, PMRT Program was only done by listening to MP3s. All participants were trained individually. Participants dressed loosely and were in a comfortable position and did PMRT according to MP3 recordings. The researchers instructed to lower the curtains and keep the surrounding environment calm before listening. Each participant could adjust the MP3 volume, there was also a replay button. MP3 officers remained with each participant until they were finished and MP3 was returned. Participants in the control group received standard post-operative intervention and education. In addition to care and education, the experimental group received the PMRT program.

The third study patients were randomly divided into two intervention groups with 20 minutes PMRT and 20 minutes $\mathrm{CM}$ five elements of music and 20 minutes of peaceful rest for each treatment and control group. The intervention was given at $10 \mathrm{am}$ or $3 \mathrm{pm}$ for 8 weeks (J. et al., 2018).

The fourth study initial research protocol required that patients only experienced 3 sessions of GI and PMR and be monitored. Interventions included: 2 minute breathing exercises, followed by 10 minutes progressive muscle relaxation exercises and 15 minute picture sessions with a pleasant guide. The control group only received regular care (standard) It was explained in international guidelines (Paikousis et al., 2016).

The fifth study intervention group was given progressive muscle training and music therapy second day (48 hours) after mastectomy, while the control group was given standard treatment. Interventions were carried out in the morning (06.00-08.00) and evening (21.00-23.00), the exercise was carried out for 30 minutes for each session 
PROFESIONAL HEALTH JOURNAL

Volume 3, No. 1, Desember 2021 (Hal. 34-42)

Available Online at https:// http://jurnal.stikesbanyuwangi.ac.id

until the patient was planned to go home (Zhou et al., 2015).

The sixth study respondents were asked to come to the right place in the hospital with a nurse. The presence of nurses was required due to the old age and they need a lot of learning. Respondents were divided into 2 groups, a group consisted of 8 people, and the second group consisted of 7 people. Education and practice sessions were different in each group, groups of 8 people got 45 minutes for 4 consecutive times after a month of education and practice. This technique was carried out for 6 months under the direct supervision of the researcher. The researcher followed up on the truth of the administration and technical over the telephone and obtained information from the patient's nurses. The control group was given three usual sessions on lifestyle and life experience (Mohsen Shahriari, Pahlavanzadeh, \& Hazini, 2017).

The seventh study all participants received guidance session to learn progressive muscle relaxation exercises following Bernstein and Borkovec. This technique consisted of subsequent contractions and relaxation in all groups, intervention sequentially. The initial position with eyes closed, the participants were instructed to contract and relax the muscles of the hands, arms, face, neck, shoulders, abdomen, and lower limbs. During the implementation of the technique, patients were suggested to do normal breathing (Fernándezde-las-Peñas et al., 2017).

The eighth study intervention is Applied Progressive Muscle Relaxation Training Program (APMRT), two hours therapy consisting of six modules. The total of three therapies was carried out by the principal researcher for six weeks. The APMRT program involved quality of life discussion in prostate cancer, rational, description and therapy demonstration. In addition, abdominal breathing techniques were taught to improve relaxation through demonstrations by the principal researcher. Patients were encouraged to practice their own therapy every day for a period of six months (Moy, Razack, Isa, Zainal, \& Zainuddin, 2013).

The ninth study involved 4 phases: T0, T1, $\mathrm{T} 2$, and $\mathrm{T} 3$. $\mathrm{T} 0$ (patient registration): all patients admitted to the hospital at least 48 hours before screening by the research nurse for inclusion / exclusion criteria. Group A patients were scheduled for individual PMR sessions - IGI. Group B received regular care. Furthermore, to avoid losing patient control (group B) from potentially favorable interventions, they were also offered PMR individual session, an IGI Session at the end of the study. T1 (24 hours from T0): GI practitioners interviewed patients who met the requirements, told them about the purpose of the study, and explained the method. T2 (in 1 hour from T1): every PMR session - IGI had duration of 20 minutes due to the patient's weak condition and difficulty concentrating for a longer period of time. T3 (within 2 hours of intervention) (D'Alete et al., 2018).

The tenth study all interventions were performed in a private room with sufficient light and warmth to make the patients feel relaxed during the study. No other individuals were allowed to enter the room during the sessions. While performing exercises, the patients were asked to wear casual and comfortable clothes. Exercises, as with reflexology, were individually performed as 16 home visits for each patient twice a week as two sessions, each for 20 minutes, for 8 weeks under the supervision of the researcher. The study design and intervention techniques were explained to each patient, who then signed an informed consent. If the patients took analgesics either orally 60 minutes or intravenously 30 minutes earlier than the intervention, the intervention was delayed to distinguish between the effects of intervention and those of the analgesic. Therefore, for the home visits, the patients were called by the researcher to evaluate the condition, and the visits were then performed according to the following arrangements. A reflexology session usually lasts for 30 minutes; therefore, two sessions were performed for a total of 60 minutes at each of the 16 home visits within an 8-week period (Dikmen \& Terzioglu, 2018).

\section{DISCUSSION}

The main purpose of this systematic review is to strengthen the evidence that Progressive Muscle Relaxation interventions (PMR) can improve cancer patients 'psychology, namely anxiety, stress, and depression to improve 
PROFESIONAL HEALTH JOURNAL

Volume 3, No. 1, Desember 2021 (Hal. 34-42)

Available Online at https:// http://jurnal.stikesbanyuwangi.ac.id

patients' quality of life. Two literatures found that there was an improvement in the patient's level of anxiety and depression as indicated by the decrease in cortisol (Charalambous et al., 2015; Kim et al., 2016). Cortisol is an important indicator of changing physiological conditions in stress response (Han, H. J., Park, A., Kim, H. S., Moon, H. K., \& Park, 2011). Other literature result showed improvements in anxiety, stress and depression, and quality of life. Another literature showed the result of improvements in physical conditions such as decreased pain, nausea, headache and prosperity level. Five studies showed improvements in psychological and physical conditions(Charalambous et al., 2015; D'Alete et al., 2018; Fernández-de-las-Peñas et al., 2017; Mohsen Shahriari et al., 2017). Three studies showed psychological improvement and quality of life without any information related to the patient's physical improvement (J. et al., 2018; Mohamad, R. I., Foong, M. M., Azad, H. A. R., Zulkifli, M. Z., \& Nor, 2013; Zhou et al., 2015). Progressive muscle relaxation is one of the complementary and alternative therapies (CAM) applied in quality of life (QOL) management (Bishop, F.L., Rea, A., Lewith, H., 2011). PMR not only one therapy that can reduced depression, stress, anxiety and increase quality of life, but also the combination of PMR with other complementary therapies can also improve depression, stress, anxiety and quality of life for patients with cancer. Intervention group receiving music therapy and progressive muscle relaxation training plus routine nursing care had significant improvement in depression and anxiety (Zhou et al., 2015). Progressive muscle relaxation, Guided imagery, and deep diaphragmatic breathing significant improvement in QoL and physical functioning (Mohsen Shahriari et al., 2017).

The weaknesses of this systematic review were the intervention of Progressive Muscle Relaxation (PMR) was done by the combination of other complementary therapies such as music, Guide Image (GI), and deep breathing. Seven literatures provided PMR therapy with combination of complementary therapies(Charalambous et al., 2015; D'Alete et al., 2018; J. et al., 2018; Zhou et al., 2015), even one of the six therapies used three therapies, ten literatures did not show disease, and the same treatment, even though the case is cancer but different treatment can cause different physical and psychological effects. Four cancer literatures in general (Charalambous et al., 2015; D'Alete et al., 2018; Fernández-de-las-Peñas et al., 2017; J. et al., 2018), a literature on colorectal cancer (Kim et al., 2016), five studies of breast cancer (Zhou et al., 2015), prostate cancer (Mohamad, R. I., Foong, M. M., Azad, H. A. R., Zulkifli, M. Z., \& Nor, 2013), and combination of both (Charalambous et al., 2015; Mohsen Shahriari et al., 2017). One literatures obtained chemotherapy treatments (Charalambous et al., 2015), one literature obtained an operating plan (Zhou et al., 2015). This systematic review were less homogeneous literatures between treatments and interventions, so the results cannot be ensured whether PMR plays full role in reducing anxiety, depression, stress and improving patients' quality of life or it was not yet clear which therapy was more effective.

\section{CONCLUSION}

The systematic review provide empirical evidence to support the propotion that Progressive Muscle in combination or without combination other complementary therapies can reduce depression, anxiety, stress and also increase quality of life in cancer patients.

\section{REFERENCES}

A. J. Mitchell, M. Chan, H. B. et al. (2011). "Prevalence of depression, anxiety, and adjustment disorder in oncological, haematological, and palliative-care settings: a meta-analysis of 94 interviewbased studies,." The Lancet Oncology, 12, 160-174.

A.F.Jorm, H.Christensen, K.M.Griffiths, R.A.Parslow, B., \& Rodgers, and K. A. B. (2004). Effectiveness of complementary and self-help treatments for anxiety disorders. Medical Journal of Australia, 181, S29-S46.

Bigliardi, P. L., Alsagoff, S. A. L., El-Kafrawi, H. Y., Pyon, J. K., Wa, C. T. C., \& Villa, M. A. (2017). Povidone iodine in wound healing: A review of current concepts and 
PROFESIONAL HEALTH JOURNAL

Volume 3, No. 1, Desember 2021 (Hal. 34-42)

Available Online at https:// http://jurnal.stikesbanyuwangi.ac.id

practices. International Journal of

Surgery, 44, 260-268.

https://doi.org/10.1016/j.ijsu.2017.06.073

Bishop, F.L., Rea, A., Lewith, H., et al.

(2011). Complementary medicine use by

men with prostate cancer: a systematic

review of prevalence studies. Prostate

Cancer Prostatic Dis, 14, 1-3.

Broadbent, E., Kahokehr, A., Booth, R. J.,

Thomas, J., Windsor, J. A., . . .

Buchanan, \& M., C. (2012). A brief

relaxation intervention reduces stress and improves surgical wound healing response: A randomized trial. Brain, Behavior, and Immunity, 26, 212-217.

C.-H. Chien, K.-L. Liu, H.-T. Chien, and H.E. L. (2014). "The effects of psychosocial strategies on anxiety and depression of patients diagnosed with prostate cancer: a systematic review,." International Journal of Nursing Studies, 28-38, 51.

Charalambous, A., Giannakopoulou, M., Bozas, E., \& Paikousis, L. (2015). A Randomized Controlled Trial for the Effectiveness of Progressive Muscle Relaxation and Guided Imagery as Anxiety Reducing Interventions in Breast and Prostate Cancer Patients Undergoing Chemotherapy. Evidence-Based Complementary and Alternative Medicine, 2015, 1-10. https://doi.org/10.1155/2015/270876

Choi, J. H., \& Kim, Y. M. (2013). (2013). Effects of aromatherapy on stress, sleep, nausea and vomiting during patient controlled analgesia treatment of patients with hysterectomy. Korean Journal of Women Health Nursing, 19, 211-218.

D'Alete, A., De Paolis, G., Mastroianni, C., Cibelli, F., Magnani, C., Surdo, L., ... Casale, G. (2018). The effectiveness of progressive muscle relaxation and interactive guided imagery as a painreducing intervention in advanced cancer patients: A multicentre randomised controlled non-pharmacological trial. Complementary Therapies in Clinical Practice, 34(December 2018), 280-287. https://doi.org/10.1016/j.ctcp.2018.12.01 4

de Souza JM, Ferrari GSL, F. C. (2017).
Correlates of geriatric depression scale with perceived quality of life in an elderly population. Geriatrics Persia, 12 .

Dikmen, H. A., \& Terzioglu, F. (2018). Effects of Reflexology and Progressive Muscle Relaxation on Pain, Fatigue, and Quality of Life during Chemotherapy in Gynecologic Cancer Patients. Pain Management Nursing, (xxxx), 1-7. https://doi.org/10.1016/j.pmn.2018.03.00 1

Donavan KA, Thompson LM, J. P. (2013). Pain, depression, and anxiety in cancer. In: Handbook of Pain and Palliative Care. Springer Publication.

Fernández-de-las-Peñas, C., Parás-Bravo, P., Salvadores-Fuentes, P., Paz-Zulueta, M., Boixadera-Planas, E., Alonso-Blanco, C., ... Santibañez-Margüello, M. (2017). The impact of muscle relaxation techniques on the quality of life of cancer patients, as measured by the FACT-G questionnaire. Plos One, 12(10), e0184147.

https://doi.org/10.1371/journal.pone.0184 147

Gaston-Johansson F, Fall-Dickson JM, Nanda JP, S. E., \& Browall M, G. N. (2013).

Long-term effect of the self-management comprehensive coping strategy program on quality of life in patients with breast cancer treated with high-dose chemotherapy. Psychooncology, 22(3), 530-539.

Gethin, G., Grocott, P., Probst, S., \& Clarke, E. (2014). Current practice in the management of wound odour: An international survey. International Journal of Nursing Studies, 51(6), 865874.

https://doi.org/10.1016/j.ijnurstu.2013.10. 013

Han, H. J., Park, A., Kim, H. S., Moon, H. K., \& Park, Y. H. (2011). The effects of laughter therapy on stress response in patients with preoperative breast cancer. Journal of Korean Oncology Nursing, 11, 93-100.

Ho, S.S., So, W.K., Leung, D.Y., Lai, E.T., Chan, C. W. (2013). Anxiety, depression and quality of life in Chinese women with breast cancer during and after 
PROFESIONAL HEALTH JOURNAL

Volume 3, No. 1, Desember 2021 (Hal. 34-42)

Available Online at https:// http://jurnal.stikesbanyuwangi.ac.id

treatment: a comparative evaluation.

European Journal of Oncology Nursing, 17, 877-882.

J., L., Y., W., Y., Z., Y.-C., Z., X., Z., N., Z., ... Y.-F., Y. (2018). Progressive Muscle Relaxation Combined with Chinese Medicine Five-Element Music on Depression for Cancer Patients: A Randomized Controlled Trial. Chinese Journal of Integrative Medicine, 24(5), 343-347. https://doi.org/10.1007/s1 1655017-2956-0 LK -

http://ucelinks.cdlib.org:8888/sfx_local?s $\mathrm{id}=$ EMBASE\&issn $=19930402 \& \mathrm{id}=$ doi: 1 0.1007\%2Fs1 1655-017-2956-

0\&atitle $=$ Progressive + Muscle + Relaxatio $\mathrm{n}+$ Combined + with + Chinese + Medicine + Five-

Element+Music + on + Depression + for $+\mathrm{Ca}$ ncer + Patients $\% 3 \mathrm{~A}+\mathrm{A}+$ Randomized + Con trolled + Trial\&stitle $=$ Chin. + J. + Integr. $+\mathrm{M}$ ed.\&title $=$ Chinese + Journal + of + Integrativ e+Medicine \&volume $=24 \&$ issue $=5 \&$ spag $\mathrm{e}=343$ \&epage $=347$ \&aulast $=$ Liao\&aufirst $=$ Juan\&auinit $=\mathrm{J} . \&$ aufull $=\mathrm{Liao}+\mathrm{J} . \& \operatorname{coden}$ $=\&$ isbn $=\&$ pages $=343$ -

$347 \&$ date $=2018 \&$ auinit $1=$ J\&aui

Kashdan TB, R. J. (2010). Psychological flexibility as a fundamental aspect of health. Clin Psychol Rev, 30(7), 865-878.

Kim, K. J., Na, Y. K., \& Hong, H. S. (2016). Effects of Progressive Muscle Relaxation Therapy in Colorectal Cancer Patients. Western Journal of Nursing Research, 38(8), 959-973. https://doi.org/10.1177/01939459166355 73

Kisner C, C. L. (2007). Therapeutic exercise: foundations and techniques 5 th ed. Philadelphia (PA) F.A. Davis Company.

Kumar S, Nayak RR, D. S. (2015).

Effectiveness Jacobson's progressive muscle relaxation technique (PMRT) to relieve anxiety among alcoholic patients MHI, SCB, Cuttack, Odisha. J Nurs Health Sci, 4, 1-6.

Larrañaga N, Galceran J, Ardanaz E, Franch P, N. C., \& Sánchez MJ, et al. (2010). Prostate cancer incidence trends in Spain before and during the prostate-specific antigen era: Impact on mortality. Annals of Oncology, 21, 83.
Lazovich D, Robien K, Cutler G, Virnig B, S. C. (2009). Quality of life in a prospective cohort of elderly women with and without cance. Cancer, 18, 115.

Medicine, I. of. (2008). Cancer Care for the Whole Patient, Institute of Medicine. Institute of Medicine, Washington, DC, USA.

Mohamad, R. I., Foong, M. M., Azad, H. A. R., Zulkifli, M. Z., \& Nor, Z. Z. (2013). Impact of applied progressive deep muscle relaxation training on the level of depression, anxiety and stress among prostate cancer patients: A quasiexperimental study. Asian Pacific Journal of Cancer Prevention, 14, 2237 2242.

Mohsen Shahriari, M. D., Pahlavanzadeh, S., \& Hazini, A. (2017). Effects of progressive muscle relaxation, guided imagery and deep diaphragmatic breathing on quality of life in elderly with breast or prostate cancerNo Title. $J$ Edu Health Promot, 6, 1.

Moy, F. M., Razack, A.-H. A., Isa, M.-R., Zainal, N.-Z., \& Zainuddin, Z. M. (2013). Impact of applied progressive deep muscle relaxation training on the health related quality of life among prostate cancer patients - A quasi experimental trial. Preventive Medicine, 57, S37-S40. https://doi.org/10.1016/j.ypmed.2013.02. 011

Newoton S, Hicky M, M. J. (n.d.). Oncology Nursing Advisor Comperhensive Guide to Clinical Practice. St. Louis: Mosby Elsevier.

Noncommunicable Disease Profile. (2007). Available from: Http://

Www.behdasht.gov.ir.pdf [Last Accessed on 2014 Jul].

Paikousis, L., Charalambous, A., Marcou, Y., Giannakopoulou, M., Bozas, E., \& Kitsios, P. (2016). Guided Imagery And Progressive Muscle Relaxation as a Cluster of Symptoms Management Intervention in Patients Receiving Chemotherapy: A Randomized Control Trial. Plos One, 11(6), e0156911. https://doi.org/10.1371/journal.pone.0156 911

ParaÂs-BravoP, S.-F., \& Alonso-BlancoC, 
PROFESIONAL HEALTH JOURNAL

Volume 3, No. 1, Desember 2021 (Hal. 34-42)

Available Online at https:// http://jurnal.stikesbanyuwangi.ac.id

Paz-ZuluetaM, SantibañezMarguÈelloM, Palacios-CeñaD, E. (2017). The impactofmusclerelaxationtechniquesonth e qualityoflife of cancerpatients, asmeasuredby theFACT-Gquestionnaire. PLoSONE12.

S. Elsenbruch, J. Langhorst, K. P. et al. (2005). Effects of mind-body therapy on quality of life and neuroendocrine and cellular immune functions in patients with ulcerative colitis. Psychotherapy and Psychosomatics, 74, 277-287.

Shahbazi K, Solati K, H.-D. A. (2016).

Comparison of hypnotherapy and standard medical treatment alone on quality of life in patients with irritable bowel syndrome: a randomized control trial. J Clin Diagn Res., 10(5), OC01OC04.

So, W.K., Marsh, G., Ling, W.M., Leung, F.Y., Lo, J.C., Yeung, M., et al., 2010. (2010). Anxiety, depression and quality of life among Chinese breast cancer patients during adjuvant therapy.

European Journal of Oncology Nursing, 14, 17-22.

T. Dehdari, A. Heidarnia, A. Ramezankhani, S.
Sadeghian, A., \& F. Ghofranipour. (2009). Effects of progressive muscular relaxation training on quality of life in anxious patients after coronary artery bypass graft surgery,". Indian Journal of Medical Research, 129, 603-608.

Wang, X.L., Jia, C.X., Liu, L.Y., Zhang, Q., Li, Y.Y., Li, L. (2013). Obesity, diabetes mellitus, and the risk of female breast cancer in Eastern China. World Journal of Surgical Oncology, 11, 71.

World Health organization. Noncommunicable Disease, Countries Profile. (2011). WHO Press, Geneva.

Zhou, K., Li, X., Li, J., Liu, M., Dang, S., Wang, D., \& Xin, X. (2015). A clinical randomized controlled trial of music therapy and progressive muscle relaxation training in female breast cancer patients after radical mastectomy: Results on depression, anxiety and length of hospital stay. European Journal of Oncology Nursing, 19(1), 54-59. https://doi.org/10.1016/j.ejon.2014.07.01 0 